DOI: https://doi.org/10.24127/ajpm.v10i4.4226

\title{
MEMAHAMI BAGAIMANA SISWA LAKI-LAKI DAN PEREMPUAN MEMECAHKAN MASALAH MATERI SISTEM PERSAMAAN LINEAR
}

\author{
Khoerul Umam**1, Dedi Hidayat ${ }^{2}$, Supandi $^{3}$ \\ ${ }^{1,2,3}$ Universitas Muhammadiyah Prof. DR. HAMKA, Jakarta, Indonesia \\ *Corresponding Author. \\ E-mail: $\quad$ khoerul.umam@uhamka.ac.id ${ }^{1)}$ \\ dedihidayat18@uhamka.ac.id $^{2 *}$ \\ supandi@uhamka.ac.id $^{3)}$
}

Received 14 September 2021; Received in revised form 16 November 2021; Accepted 21 December 2021

\begin{abstract}
Abstrak
Kemampuan pemecahan masalah matematika dipengaruhi oleh kemampuan siswa dalam mematematisasi masalah. Dalam memahami bagaimana proses itu terjadi dapat dieksplorasi, salah satu cara mengeksplorasi kemampuan pemecahan masalah matematika dapat menggunakan materi sistem persamaan linear. Materi ini memungkinkan siswa untuk mengembangkan pengetahuan matematika melalui pemecahan masalah. Metode penelitian yang digunakan metode deskriptif kualitatif guna untuk mendeskripsikan kemampuan pemecahan masalah pada siswa dalam materi persamaan linier ditinjau dari kamampuan matematis. Instrumen penelitian ini menggunakan materi system persamaan linear yang mengharuskan siswa mengembangkan kemampuan pemecahan masalah matematisnya. Data penelitian divalidasi dengan menggunakan triangulasi waktu dan sumber agar didapatkan data penelitian yang reliabel dan valid. Analisis data menggunakan analisis deskriptif berdasarkan indikator pada kemampuan pemecahan masalah. Hasil Penelitian ini menunjukkan bahwa siswa telah memahami urutan dalam langkah-langkah memecahkan masalah pada persoalan system persamaan linear dua variabel. Perbedaan mendasar dapat dilihat ketika siswa perempuan lebih mendetailkan seluruh informasi yang didapatkan sedangkan siswa laki-laki cenderung menghabiskan waktu untuk membaca masalah tetapi tidak mendetailkan informasi yang didapatkan. Kecenderungan yang berbeda bagaimana siswa perempuan dan laki-laki mengawali proses pemecahan masalah matematika dapat membantu guru untuk tahapan dan langkah apa yang diperlukan dalam mengembangkan kualitas pembelajaran matematika yang lebih berkelanjutan.
\end{abstract}

Kata Kunci: Gender; Kemampuan Pemecahan Masalah Matematis.

\begin{abstract}
Mathematical problem solving ability is influenced by students' ability to mathematize problems. In understanding how the process occurs can be explored, one way to explore mathematical problem solving skills can be using the material system of linear equations. This material allows students to develop mathematical knowledge through problem solving. The research method used is descriptive qualitative method in order to describe the problem solving ability of students in linear equation material in terms of mathematical ability. This research instrument uses a system of linear equations which requires students to develop their mathematical problem solving skills. The research data was validated by using time and source triangulation in order to obtain reliable and valid research data. Data analysis used descriptive analysis based on indicators on problem solving ability. The results of this study indicate that students have understood the sequence of steps in solving problems in a two-variable system of linear equations. The basic difference can be seen when female students are more detailed in all the information obtained while male students tend to spend time reading problems but do not detail the information obtained. The different trends in how female and male students initiate the process of solving mathematics problems can help teachers to determine what stages and steps are needed in developing a more sustainable quality of mathematics learning.
\end{abstract}

Keywords: Gender; Mathematical Problem Solving Ability.

This is an open access article under the Creative Commons Attribution 4.0 International License 
DOI: https://doi.org/10.24127/ajpm.v10i4.4226

\section{PENDAHULUAN}

Proses pembelajaran matematika memerlukan beberapa kemampuan yang harus dimiliki siswa untuk dapat mencapai tujuan pembelajaran terutama kemampuan pemecahan masalah(NCTM, 2000; Phonapichat et al., 2014; Radford, 2008). Pemecahan masalah dalam matematika merupakan salah satu kegiatan sentral dalam kurikulum matematika sekolah saat ini. Pemecahan masalah berhubungan dengan penemuan, berbasis logika sebagai sarana penemuan induktif dan deduktif dalam pengambilan keputusan yang berorientasi pada tujuan untuk mencari solusi dari permasalahan yang dihadapi khusunya saat memecahkan soal-soal matematika (Alexander, 2012; Ike \& Suhendri, 2021; Norqvist, 2018; Saida et al., 2021; Umam, 2018).

Kurikulum 2013 disiapkan untuk menghadapi tantangan dari rendahnya kemampuan matematis siswa (Alawiyah, 2013; Saida et al., 2021; Warli, 2014). Berbagai aspek disiapkan dalam kurikulum 2013, dikembangkan dalam menyiapkan generasi mendatang yang lebih baik dan mempunyai karakter. Aspek penting guna mencapai tujuan proses pembelajaran salah satunya perencanaan guru dalam mengantisifasi kebutuhan serta materi maupun model pembelajaran yang digunakan (Octaviani et al., 2021; Saida et al., 2021; Wahyudin, 2008)

Pemecahan masalah memiliki karakteristik aktivitas matematika dapat digunakan sebagai cara mengembangkan pemahaman matematika. Hal ini menyiratkan bahwa pemecahan masalah bagian tidak terpisahkan dari pembelajaran matematika(Al-Emran et al., 2020; Karim et al., 2021). Selanjutnya, siswa belajar untuk menerapkan keterampilan matematika mereka dengan cara baru; mengembangkan pemahaman yang lebih dalam tentang ide-ide matematika dan merasakan pengalaman menjadi seorang matematikawan melalui pemecahan masalah. Oleh karena itu, siswa mampu mengembangkan pengetahuan, pemecahan masalah yang diberikan, menerapkan dan menggunakan berbagai strategi, dan juga mencerminkan dan memantau proses pemecahan masalah.

Proses pemecahan masalah memerlukan penerapan strategi tertentu, yang dapat menyebabkan pemecahan masalah untuk mengeksplorasi beberapa ide dengan mengembangkan dan menguji hipotesis(Lipnevich \& Smith, 2009; Passolunghi et al., 2016). Dalam proses untuk menemukan solusi atas masalah yang diberikan, siswa harus memanfaatkan pengetahuannya, yang melaluinya mereka sering kali mampu mengembangkan pemahaman matematika baru(Hastuti et al., 2021; Ikram \& Ikram, 2021). Kemampuan masalah matematis berperan sangat penting bagi siswa menghadapi masalah pada matematika atau kehidupan nyata (NCTM, 2000).

Peran Gender (Gender role) merupakan ekspektasi sosial yang merumuskan mengenai pria serta wanita dalam proses berfikir, merasa, maupun berbuat. Jenis kelamin (Gender) dapat dimaknai sebagai perbedaan antara pria dan wanita. Berdasarkan hal tersebut, maka diduga terdapat perbedaan kemampuan pemecahan masalah antara siswa lakilaki dan siswa perempuan.

Perbedaan antara laki-laki dan perempuan juga dapat dieskplorasi dalam aspek pemecahan matematika. Salah satu cara mengeksplorasi dengan menggunakan masalah matematika 
pada materi system persamaan linear dua variabel. Dengan memahami bagaimana cara siswa perempuan dan laki-laki memecahkan masalah matematika akan membantu banyak hal dalam meningkatkan kualias pembelajaran matematika. Penelitian ini akan mengeksplorasi bagaimana siswa perempuan dan laki-laki memecahkan masalah matematika.

\section{METODE PENELITIAN}

Jenis penelitian yang digunakan yaitu deskriptif kualitatif guna mendeskripsikan profil kemampuan pemecahan masalah siswa pada materi persamaan linier ditinjau dari kamampuan matematis. Siswa terlebih dahulu dibagi menjadi tiga kelompok berdasarkan kemampuan matematis, kemudian diberikan soal system persamaan linear yang berisi soal cerita untuk mengetahui profil kemampuan pemecahan masalah masing-masing kelompok. Hasil dari jawaban peserta didik selanjutnya dianalisis yang sesuai pada indicator hasil kemampuan peserta didik pada pemecahan masalah.

Subjek dalam penelitian ini adalah siswa kelas IX-1 dan IX-2 SMP tahun ajaran 2020/2021. Jumlah siswa sebanyak 60, kemudian dikelompokkan berdasarkan gender yaitu 22 siswa lakilaki dan 38 siswa perempuan. Data demografi juga menyajikan bagaimana prilaku siswa belajar matematika selama pandemi yang terbagi menjadi tiga kategori yaitu 6 jam sebanyak 25 siswa, < 9 jam sebanyak 29 siswa, dan 10-12 Jam sebanyak 6 siswa. Untuk lebih jelas melihat bagaimana demografi subjek dapat terlihat pada Tabel 1. Teknik pengambilan data merupakan langkah yang paling utama dalam penelitian, karena tujuan utama dari penelitian adalah mendapatkan data. Teknik Pengambilan data yang dilakukan dengan cara memberikan soal berbentuk soal cerita tentang permasalahan konstekstual pada materi sistem persamaan linear kepada siswa laki-laki dan perempuan untuk menguji kemampuan siswa dalam menyelesaikan soal cerita tersebut.

Tabel 1. Demografi Sampel

\begin{tabular}{lll}
\hline Katagori & & Jumlah \\
\hline Gender & Laki-laki & 22 \\
\hline & Perempuan & 38 \\
\hline $\begin{array}{l}\text { Belajar } \\
\text { selama } \\
\text { pandemic } \\
\text { berapa } \\
\text { lama }\end{array}$ & 6 jam & 25 \\
\cline { 2 - 3 } $\begin{array}{l}<9 \text { jam } \\
\text { Kuata } \\
\text { internat }\end{array}$ & $10-12$ Jam & 6 \\
\cline { 2 - 3 } & Data seluler & 10 \\
\cline { 2 - 3 } & $\begin{array}{l}\text { Wifi } \\
\text { Menggunakan }\end{array}$ & 1 \\
\hline
\end{tabular}

Selanjutnya, memilih peserta didik laki-laki atau perempuan kemudian peserta didik tersebut diminta untuk menyelesaikan pada permasalahan yang berkaitan dengan materi system persamaan linear. Setelah mengerjakan soal sistem persamaan linear diperoleh, penskoran pada butir indikator untuk mendapatkan persentase pemecahan masalah serta rata-rata kemampuan pemecahan masalah. Wawancara siswa laki-laki dan perempuan untuk mengetahui jawaban yang sudah dituliskan mulai dari memahami masalah soal yang diberikan, menyusun rencana jawaban yang akan dikerjakan, melakasanakn perencanaan dengan menjawab soal dengan benar dan memeriksa Kembali jawaban yang sudah dikerjakan.

Transkipsi dari hasil wawancara peserta didik laki-laki dan perempuan diminta untuk mendeskripsikan kemampuan atau pemahaman pada pemecahan masalah matematis, peserta didik dalam menyelesaiakan soal cerita 
yang berkaiatan dengan sistem persamaan linear dua variabel dari hasil wawancara sampai kepada faktor pendukung internet yang di gunakan.

Analisis data dilakukan melalui beberapa tahapan. Adapun tahapan menganalisis data yaitu: mempelajari data, mengklasifikasikan dan menentukan profil. Tahap mempelajari data, dilakukan dengan cara : mengumpulkan hasil dari pekerjaan peserta didik dalam menyelesaikan latihan atau tugas yang diberikan, membaca dengan seksama hasil pekerjaan siswa, sehingga diperoleh analisa atau pengamatan awal tentang: bagaimana cara peserta didik dalam menyelesaikan soal, untuk menggali informasi dari peserta didik apa saja yang dilakukan atau digunakan peserta didik sebagai acuan pada penyelesaian soal.

Tahap mengklasifikasikan data hasil kerjaan siswa dianalisis berdasarkan indikator kemampuan pada pemecahan masalah, sedangkan hasil wawancara dianalisis dengan teknik yang dinyatakan Miles dan Huberman (1994) yaitu reduksi data, penyajian data dan penarikan kesimpulan (Miles, M. B., \& Huberman, 1994).

\section{HASIL DAN PEMBAHASAN}

Kemampuan Pemecahan Masalah
Matematis Siswa Perempuan Pada
Sistem Persamaan Linear Dua
Variabel
Pada tahapan selanjutnya, peneliti akan menyajikan bagaimana mayoritas siswa dengan jenis kelamin perempuan memecahkan masalah matematika. Penyajian pembahasan ini hanya representasi dari 38 siswa perempuan yang diwawancarai oleh peneliti.

\section{Memahami Masalah}

Saat S1 diberikan soal, S1 langsung membaca soal cerita dengan teliti dan memahami soal dengan baik terlihat dari jawaban MMS1001, kemudian langsung mengerjakan pada kertas yang sudah disediakan dengan menulis variabel terlebih dahulu dari soal cerita yang diberikan terlihat dari Gambar 1, S1 mencoba mengingat kembali jenis soal dan cara pengerjaan yang telah dipelajari sebelumnya sehingga S1 dapat memahami urutan langkah-langkah dalam pengerjaan soal secara lengkap terlihat dari Gambar 1 Bukti wawancara sebagai berikut:

$P \quad:$ Apa yang kamu pikirkan saat melihat soal tersebut?

S1 : Ini soal tentang sistem persamaan linera dua variabel,

$P \quad$ : Informasi apa saja yang kamu peroleh dari soal tersebut?

S1 : dimisalkan dulu, karena ada 2 variabel

$P$ : Apakah sekarang sudah paham belum maksud dari soal tersebut?

S1 : Alhamdulillah sudah Pak,

$P$ : Bagaiaman Langkah memahami masalah

S1 : membaca soal dengan cermat kemudian dijadikan dalam bentuk matematika agar mempermudah menyelesaikan soal

$$
\begin{aligned}
& \text { Jumlah dua bilangan adalah } 200 \text { dan selisih } \\
& \text { bilangon tersebut adalah 108, tentukan bilangan } \\
& \text { yang paling besar drantara kedvanya. } \\
& \text { diketabui: } a+b=200 \\
& \qquad a-b=108
\end{aligned}
$$

Gambar 1. Tulisan siswa memahami masalah.

Berdasarkan hasil pekerjaan serta wawancara dengan S1 (Gambar 1), terlihat bahwa S1 mampu menyelesaikan masalah dengan baik. S1 mampu menjelasakan informasi dari 
DOI: https://doi.org/10.24127/ajpm.v10i4.4226

soal yang diberikan dengan baik dan akurat yaitu diketahui dan ditanya, membuat perencanaan dalam menyelesaikan masalah sesuai prosedur, serta memeriksa kembali hasil pekerjaan. S1 mampu melakukan empat tahapan pemecahan masalah menurut Polya, sehingga S1 tergolong siswa dengan kategori memiliki kemampuan pemecahan masalah matematis tinggi (Fatmawati \& Murtafiah, 2018; Samo, 2017; Sari, 2017; Sumartini, 2016).

\section{Menyusun Rencana}

Dalam menyusun rencana $\mathrm{S} 1$ mencoba menggunakan simbol-simbol dalam bentuk variabel. S1 mencoba menuliskan persamaan dengan dua variable dari soal cerita, kemudian menuliskan susunan persamaan linear dua variabel berikutnya sesuai dengna soal yang ada. Hal ini ia lakukan untuk mempermudah dalam menyelesaikan persamaan linear dua variabel. Kemudian menghubungkanya guna menyesuaikan dengan rumus yang diingat dapat dilihat pada Gambar 2.

P : Dari soal tersebut, hal apa yang pertama kamu tuliskan?

S1 : Saya menulis semua yang diketahui dari soal, dan menentukan variable a dan $b$ karena ada dua bilangan dan menuliskan apa yang menjadi pertanyaan.

$\mathrm{P}$ : Setelah itu, rencana selanjutnya apa?

S1 : membuat persamaan 1 dan 2 dari soal cerita

$\mathrm{P} \quad$ : Mengapa dalam mengerjakan soal ini kamu tulis semua yang diketahui dan menuliskan rumusnya?

$\mathrm{S} 1$ : Untuk memudahkan dalam memahami soal, dan langsung bisa di kerjakan

$$
\begin{gathered}
\text { diketahui: } \begin{aligned}
a+b & =200 \\
a-b & =108
\end{aligned} \\
\text { ditanya: bilangan terbesar }
\end{gathered}
$$

Gambar 2. S2 menyusun rencana penyelesaian masalah
Indikator pemecahan masalah akan terpenuhi ketika siswa dapat menerapkan strategi yang tepat untuk menyelesaikan soal serta melakukan perhitungan dengan benar(Abdullah et al., 2015; Schukajlow et al., 2015).

\section{Melaksanakan Perencanaan}

S1 setelah mencoba untuk menyusun rencana melanjutkan dengan menyelesaikan system persamaan linear dua variabel dengan cara eliminasi untuk mencari salah satu variable dari soal tersebut terlihat dari jawaban kemudian memasukan nilai variabel yang sudah diketahui kedalam salah satu persamaan untuk mencari variabel yang lainnya terlihat dari Gambar 3, S1 melakukan pengerjaan soal cerita sesuai prosedur dengan tepat sehingga mampu menjawab soal tersebut dengan benar.

$P \quad$ : Setelah menulis semua yang diketahui dan rumus, langkah selanjutnya?

S1 : menyelesaikan system persamaan linear dua variable dengan cara eliminasi untuk mencari satu variable kemudian di apabila variable sudan dapat kita masukan ke salah satu persamaan tersebut

$P$ : Dalam perhitungan, kamu termasuk anak yang teliti atau kadang terburu-buru?

S1 : insya allah saya teliti dalam mengerjakannya.

$P$ : Nah loh, tahu salah dari mana?

S1: karena kalua saya buktikan hasil yang didapat ke persamaan diatas benar.

$$
\begin{aligned}
& \text { jawas: } a+b=200 \\
& \frac{a-b=108}{2 b=92} \\
& \begin{aligned}
2 b & =46
\end{aligned} \\
& \text { persamian 1-p } a+(46)=200 \\
& a=200 \cdot 46=154 \\
& \text { Jadi bilangan terbesar dari keduanya } \\
& \text { adalan } 154
\end{aligned}
$$

Gambar 3. jawaban subjek dalam melaksanakan perencanaan 
DOI: https://doi.org/10.24127/ajpm.v10i4.4226

\section{Memeriksa Kembali}

Dari hasil percakapan sebelumnya, terlihat bahwa S1 setelah selesai mengerjakan soal memeriksa jawaban kembali dan membuktikan jawaban yang sudah diketahui kepada persamaan yang yang awal terlihat dari jawaban untuk menyakinkan bahwa jawaban tersebut benar terlihat dari Gambar 4 sehingga S1 termasuk anak dalam kategori memeriksa kembali dalam melakukan proses pemecahan soal yang diberikan.

$P$ : Jawaban yang kamu kerjakan benar,

S1: Insya Allah benar, karena sudah saya buktikan

$P$ : Apakah setiap mengerjakan soal matematika, sebelum kamu kumpulkan selalu dikoreksi dulu?

S1: Ya Pak, untuk memastikan kebenarannya.

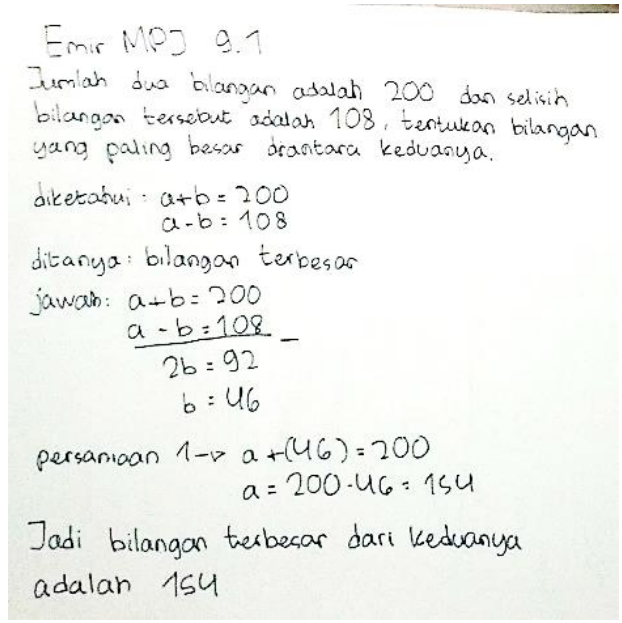

Gambar 4 Hasil jawaban subjek 1

(Memeriksa Kembali jawaban)

Kesalahan dalam melaksanakan rencana biasanya terlihat dari tidak sesuainya model matematika serta langkah penyelesaian, menguasai sebagian konsep dan strategi pengerjaan (Isnaeni et al., 2018; Komarudin, 2016; Nurdiana, 2017). Dalam memeriksa kembali perlu menjadi perhatian khusus karena proses memeriksa kembali merupakan hal penting dalam pemecahan masalah matematis guna meminimalisir kesalahan teknis, namun tidak sedikit siswa merasa bingung apa yang mesti dilakukan dalam proses memeriksa kembali (Irfan, 2017; Kristofora \& Sujadi, 2017; Ruswati et al., 2018).

\section{Kemampuan Pemecahan Masalah Siswa Laki-laki memecahkan masalah matematika Pada Sistem Persamaan Linear Dua Variabel}

Paparan data subjek penelitian dari jenis kelamin laki-laki ini merupakan represetansi dari 22 siswa yang sudah diwawancarai oleh peneliti. Untuk mendapatkan penjelasan lebih rinci tentang bagaimana subjek laki-laki memecahkan masalah dapat disajikan sebagai berikut.

\section{Memahami Masalah}

S2 memahami masalah dengan cara membaca masalah secara berulang pada kata-kata yang diasumsikan memiliki tingkat kepentingan yaitu jumlah dan selisih. S2 memandang kedua kata kunci tersebut menjadi awal dalam memahami masalah matematika yang ada. Ketika sudah memahami maksud diantara jumlah bilangan dan selisih bilangan, maka masalah matematika ini dapat dengan mudah diselesaikan. Hal ini dapat terlihat dari hasil wawancara sebagai berikut.

P: Apa yang ada dipikiranmu saat melihat masalah ini?

S2: saya membutuhkan waktu beberapa kali untuk membaca masalah

P: Lalu apa yang kamu baca berkali-kali? 
DOI: https://doi.org/10.24127/ajpm.v10i4.4226

S2: saya membaca kata "jumlah", selisih, terbesar dan Dua bilangan.

$P$ : selanjutnya

S2: saya akhirnya menuliskan dua bilangan itu sebagai a dan $b$.

$P$ : apa itu huruf " $a$ " dan " $b$ " S2: a adalah bilangan pertama, sedangkan $b$ adalah bilangan kedua. Dan yang dicari itu bilangan terbesar.

$$
\begin{aligned}
& \text { Jumbar dua bilangan addalah } 200 \text { dan selinh } \\
& \text { bilangan tersebut adah 108. Tentuhan bilangan } \\
& \text { yany paling besar diantara keduarya. } \\
& \text { ditanya: bilagn tervesar }
\end{aligned}
$$

Gambar 5. S2 memahami masalah matematika

Tahapan memahami masalah yang dilakukan S2 (Gambar 5) dengan membaca berulang kali sebagai bagian dari tahapan konfirmasi. S2 terlihat melakukan fokus setelah mengkonfirmasi masalah matematika secara berulang. Ia memfokuskan pada kata "jumlah bilangan" dan selisih bilangan. Kedua kata tersebut menjadi kunci bagaimana S2 memahami masalah. Hal ini juga dapat terlihat saat S2 memberikan penekanan atas informasi yang dapat di lihat pada Gambar5.

\section{Menyusun Rencana}

Setelah S2 memahami kedua kata kunci tersebut, ia mulai menyusun rencana dengan melakukan proses matematisasi kalimat menjadi pernyataan matematika. Dari Gambar 6 ini dapat terlihat pada saat S2 menuliskan $\mathrm{a}+\mathrm{b}=200$ dan $\mathrm{a}-\mathrm{b}=108$. Persamaan matematika yang S2 tuliskan merupakan representasi bagaimana S2 memahami masalah dengan baik. S2 merencanakan menggunakan subtitusi dan eleminasi dalam menyelesaikan masalah. Hal ini dapat terlihat pada data wawancara sebagai berikut.

P: setelah menuliskan a dan $b$, lalu bagaimana?

S2: saya tuliskan dulu bahwa jumlah bilangan 200 itu artinya $a$ ditambah $b$ sama dengan 200 , trus $a-b$ sama dengan 108.

P: apa gunanya menuliskan hal itu?

S2: setelah menuliskan itu kan kita bisa mencari nilai a dan $b$ dengan cara eleminasi. Setelah dapat nilai a atau b nya kita bisa subtitusi.

$$
\begin{aligned}
& \text { ditonya: bilagen terpesar } \\
& \text { jawatio Persin: } \begin{aligned}
a+b & =200 \\
a-b & =108+
\end{aligned}
\end{aligned}
$$

Gambar 6. S2 menyusun Rencana Penyelesaian Masalah

$$
\text { Kemampuan mengkonversi }
$$
kalimat menjadi penulisan secara matematika menunjukkan bahwa S2 memahami dengan baik masalah matematika dan konsep matematika dengan baik. Siswa yang dapat menjelasakan bagaimana kalimat menjadi matematika dapat dikategorikan siswa yang memahami masalah dengan baik. Kemampuan tersebut tidak hanya membuktikan bahwa siswa tersebut memahami konsep tetapi juga dapat mengintegrasikan antara konsep matematika dan masalah matematika yang kemudian disajikan dalam suatu model.

\section{Melaksanaan Perencanaan}

S2 terlihat mengetahui tahapan bagaimana menyelesaikan masalah ini 
dengan baik pada saat wawancara sebelumnya menyebutkan eleminasi dan subtitusi. Hal ini juga terlihat pada tahapan bagaimana S2 melakukan eleminasi dari dua persamaan yang ada (Gambar 7). Hal ini dapat terlihat dari wawancara sebagai berikut.

\section{P: bagaimana langkah yang kamu lakukan? \\ S2: setelah saya tuliskan $a+b=200$ dan $a-b=108$, saya mau mencari nilai a terlebih dahulu, maka saya hilangkan $b$ dengan cara menjumlahkan kedua persamaan. $2 a=308$.. berarti nilai a itu 154 . P: setelah dapat nilai a, bagaimana?}

S2: saya lakukan subtiusi, nilai a saya masukkan ke salah satu persamaan. $a-b=108$. Saya ganti nilai a menjadi 154 sehingga saya dapatkan nilai $b$ itu 46. Jadi nilai terbesarnya yaitu 154.

$$
\text { Perim: } \begin{array}{rlrl}
a+b & =200 & \sim a-b & =108 \\
a-b & =108+154-b= & 108 \\
\hline 2 a & =308 \\
a & =\frac{308}{2} \\
a & =154 & 154-108 & =b \\
46 & =b
\end{array}
$$

Gambar 7. Siswa menyelesaikan Masalah dengan subtitusi dan eliminasi

Pemilihan tahapan penyelesaian yang baik dapat terlihat bagaimana siswa memilih eleminasi terlebih dahulu. S2 mengeleminasi dua persamaan untuk mendapatkan nilai a. Hal ini membuktikan bahwa kemampuan siswa dalam memecahkan masalah didukung oleh kemampuan pemahaman konsep matematika yang baik. Setelah mendapatkan nilai a, siswa tidak mengulang cara

\section{Memeriksa Kembali}

Keberhasilan S2 dalam menerapkan konsep eleminasi dan subtitusi pada penerapan perencanaan memberikan keyakinan yang sangat baik sehingga timbul keyakinan bahwa hasil jawaban yang sudah diperoleh sudah benar. Hal ini dapat terbukti dari wawancara sebagai berikut.

P: apakah kamu sudah yakin atas jawabannmu?

S2: saya yakin atas jawaban saya.

P:apakah kamu perlu memeriksakan kembali jawabanmu?

S2: tidak perlu...sudah cukup dari pengurangan antara 154-108 itu kita dapat nilai b. sehingga didapatkan bahwa 154 itu data terbesar.

Pemahaman konsep yang sangat baik dari tahapan perencanaan menyebabkan S2 tidak membutuhkan tahapan pemeriksaan kembali. Hal ini karena kemampuan mengeliminasi dan mensubtitusi yang dapat dilakukan secara bersamaan. Kemampuan untuk mengeleminasi dan subtitusi dalam satu tahapan penyelesaian membuktikan pemahaman yang baik dari konsep matematika. Siswa yang dapat mengkombinasikan dua konsep dalam tahapan penyelesaian membuktikan kemampuan yang baik dalam memecahkan masalah matematika (Guerrero-Ortiz et al., 2017; Kurniasih et al., 2021; Maesya Firdaus et al., 2021; Webb et al., 2013).

Berdasarkan analisis data, peneliti dapat menarik kesimpulan bahwa siswa perempuan dalam Memahami soal dengan baik ditandai dengan menuliskan semua yang diketahui dan ditanya dengan akurat. Dalam merencanakan penyelesaikan, ia menuliskan rumus yang akan digunakan sesuai dengan apa yang ditanya dengan 
DOI: https://doi.org/10.24127/ajpm.v10i4.4226

akurat. Kemampuan tersebut, selanjutnya digunakan untuk melakukan pemecahan masalah dengan baik, rapi dan benar dalam operasi hitung serta dapat menarik kesimpulan dengan benar. Siswa perempuan kebayakan dari subjek yang diteliti melakukan pemeriksaa kembali jawaban dari soal dan yakin akan jawaban yang didapat.

Hal berbeda dengan kebayakan siswa laki-laki, setidaknya memahami soal dengan membaca berulang, mengungkapkan apa yang diketahui tetapi tidak boleh menuliskan dengan apa yang akan ditanyakan dari soal. Siswa laki-laki cenderung untuk tidak boleh menuliskan rencana pemecahan masalah tetapi menuliskan fakta-fakta penting yang terdapat di masalah. Menuliskan pemecahan masalah dengan rapi dan dapat menarik kesimpulan dengan benar Langkah-langkah penyelesian dapat dilakukan dengan benar. Siswa laki-laki juga cenderung untuk tidak melakukan memeriksa kembali jawaban karena merasa yakin akan jawaban yang didapat.

Peneliti melihat bagaimana kecenderungan perempuan dalam banyak details sedangkan siswa lakilaki tidak mendetailkan informasiinformasi. Kebiasaan mendetailskan suatu masalah matematika membantu siswa perempuan dalam memahami masalah dengan baik. Hal berbeda dengan siswa laki-laki yang mayoritas ingin menyelesaikan masalah matematika dengan cepat tetapi tidak mendetailskan permasalahan dapat mengakibatkan kesalahan dalam pengambilan keputusan yang tepat dalam memecahkan masalah matematika.

\section{KESIMPULAN DAN SARAN}

Data penelitian menunjukkan bahwa siswa dengan jenis kelamin laki-laki dan perempuan melakukan tiga tahap pemecahan masalah yang sama yaitu memodelkan masalah, mengeliminasi, dan mensubtitusi. Dalam memodelkan masalah matematika, siswa perempuan lebih detail pada masalah matematika, sedangkan siswa laki-laki cenderung fokus pada kata kunci. Pemahaman masalah yang berbeda ini dapat diinterpretasi bahwa siswa perempuan lebih fokus pada hal yang sangat detail tetapi juga tidak mengecilkan informasi secara keseluruhan. Berbeda dengan siswa laki-laki yang membutuhkan waktu untuk mencari kata-kata kunci sebelum akhirnya dapat memodelkan masalah. Perbedaan yang dapat didapat dari penelitian ini juga, kecenderungan siswa perempuan untuk lebih teliti dibandingkan dengan siswa laki-laki pada saat memerikan kembali jawaban yang sudah diperoleh.

Pemaparan data yang hanya dalam cakupan yang kecil yaitu 22 siswa perempuan dan 38 siswa perempuan, ada kemungkinan kesalahan data dalam memahami bagaimana siswa laki-laki dan perempuan. Penelitian yang akan datang perlu memperluas jumlah subjek penelitian yang dapat mengambil dari jumlah sekolah yang berbeda-beda. Dengan fijomemahami secara detail bagaimana prilaku siswa perempuan dan laki-laki dalam memecahkan masalah, hal ini dapat memberikan perbaikan kualitas pembelajaran secara berkesinambungan. Penggunaan metode pembelajaran berbasis masalah serta masalah-masalah yang diberikan hendaknya memberikan arah untuk melatih pemecahan masalah. Sesuatu yang dilatih dengan terus menerus akan menjadikan sebuah kebiasaan, sehingga kemampuan dalam pemecahan masalah semua peserta didik dapat mencapai secara utuh atau keseluruhan. 
DOI: https://doi.org/10.24127/ajpm.v10i4.4226

\section{UCAPAN TERIMA KASIH}

Penelitian dan publikasi ini didanai oleh RAPB Universitas Muhammadiyah Prof. DR. HAMKA, hibah Penelitian internal dengan nomor 658/ F.03.07 / 2021.

\section{DAFTAR PUSTAKA}

Abdullah, A. H., Abidin, N. L. Z., \& Ali, M. (2015). Analysis of students' errors in solving Higher Order Thinking Skills (HOTS) problems for the topic of fraction. Asian Social Science, 11(21), 133142.

https://doi.org/10.5539/ass.v11n21 p133

Al-Emran, M., Arpaci, I., \& Salloum, S. A. (2020). An empirical examination of continuous intention to use m-learning: An integrated model. Education and Information Technologies, 25(4), 2899-2918.

https://doi.org/10.1007/s10639-

019-10094-2

Alawiyah, F. (2013). Peran Guru dalam Kurikulum 2013. Aspirasi, 4(1), 65-74.

Alexander, P. a. (2012). How We Think: A Theory of Goal-Oriented Decision Making and Its Educational Applications, by Alan H. Schoenfeld . Mathematical Thinking and Learning, 14(3), 257-263.

https://doi.org/10.1080/10986065.2 012.683320

Fatmawati, F., \& Murtafiah, M. (2018). Deskripsi Kemampuan Pemecahan Masalah Peserta Didik Kelas XI Sma Negeri 1 Majene. Saintifik, 4(1), 63-73. https://doi.org/10.31605/saintifik.v $4 \mathrm{i} 1.145$
Guerrero-Ortiz, C., Mena-Lorca, J., \& Soto, A. M. (2017). Fostering Transit between Real World and Mathematical World: Some Phases on the Modelling Cycle. International Journal of Science and Mathematics Education, 596, $1-24$.

https://doi.org/10.1007/s10763017-9856-9

Hastuti, E. S., Eclarin, L., \& Dalam, K. K. S. (2021). Kecemasan Siswa Sekolah Menengah Pertama Menyelesaikan Masalah SPLDV Pada Kelas Virtual Dalam. International Journal of Progressive Mathematics Education, 1(1), 64-84. https://doi.org/10.22236/ijopme.v1 i1.6914

Ike, F., \& Suhendri, H. (2021). Analisis Kemampuan Pemahaman Konsep Matematis Siswa Kelas V Pada Materi Kubus Dan Balok. International Journal of Progressive Mathematics Education, 1(2). https://doi.org/10.22236/ijopme.v1 i2.7308

Ikram, M., \& Ikram, M. (2021). Analysis of The Occurrence of Reversible Reasoning for Inverse Cases: A Case Study on The Subject Adjie. International Journal of Progressive Mathematics Education, 8435(1), $1-15$.

https://doi.org/10.22236/ijopme.v1 i1.6635 To

Irfan, M. (2017). Analisis Kesalahan Siswa dalam Pemecahan Masalah Berdasarkan Kecemasan Belajar Matematika. Kreano, Jurnal Matematika Kreatif-Inovatif, 8(2), 143-149.

https://doi.org/10.15294/kreano.v8i 2.8779 
Isnaeni, S., Fajriyah, L., Risky, E. S., Purwasih, R., \& Hidayat, W. (2018). Analisis Kemampuan Penalaran Matematis dan Kemandirian Belajar Siswa SMP pada Materi Persamaan Garis Lurus. Journal of Medives: Journal of Mathematics Education IKIP Veteran Semarang, 2(1), 107. https://doi.org/10.31331/medives.v $2 \mathrm{i} 1.528$

Karim, A., Soebagyo, J., \& Edy Purwanto, S. (2021). Stochastic Block Model Reveals Maps of In Applied Mathematics Studies Using VOS Viewer. International Journal of Progressive Mathematics Education, 1(2), 127142.

https://doi.org/10.22236/ijopme.v1 i2.6917

Komarudin. (2016). Analisis Kesalahan Pemecahan Masalah Matematika pada Materi Peluang Berdasarkan High Order Thinking. Jurnal Pendidikan, Komunikasi Dan Pemikiran Hukum Islam, VIII(1), 202-217.

Kristofora, M., \& Sujadi, a a. (2017). Analisis Kesalahan Dalam Menyelesaikan Masalah Matematika Dengan Menggunakan Langkah Polya Siswa Kelas Vii Smp. Prisma, 6(1), 9-16. https://doi.org/10.35194/jp.v6i1.24

Kurniasih, N., Hidayani, F., \& Muchlis, A. (2021). Analisis Kemandirian Belajar Matematika Siswa SMA Kelas XI Selama Pembelajaran Jarak Jauh. International Journal of Progressive Mathematics Education, 1(2), 117-126. https://doi.org/10.22236/ijopme.v1 i2.6568

Lipnevich, A. A., \& Smith, J. K. (2009). "I really need feedback to learn:"
Students' perspectives on the effectiveness of the differential feedback messages. Educational Assessment, Evaluation and Accountability, 21(4), 347-367. https://doi.org/10.1007/s11092009-9082-2

Maesya Firdaus, D., Purwanto, S. E., \& Nuriadin, I. (2021). Kontribusi Seft-Efficacy Dan Mathematics Anxiety Terhadap Kemampuan Penalaran Matematika Siswa. International Journal of Progressive Mathematics Education, 1(2), 1-19. https://doi.org/10.22236/ijopme.v1 i2.6488

Mathematics, N. C. of T. of. (2000). Principles and standards for School Mathematics.

Miles, M. B., \& Huberman, A. M. (1994). Qualitative data analysis: An expanded sourcebook. In CEUR Workshop Proceedings (Vol. 1304, pp. 89-92). SAGE Publications.

NCTM. (2000). A Vision for School Mathematics. Principles and Standards for School Mathematics, 3-8.

Norqvist, M. (2018). The effect of explanations on mathematical reasoning tasks. International Journal of Mathematical Education in Science and Technology, 49(1), 15-30. https://doi.org/10.1080/0020739X. 2017.1340679

Nurdiana. (2017). Analisis Kesalahan Siswa Menurut Kastolan Dalam Pemecahan Masalah Matematika. Seminar Matematika Dan Pendidikan Matematika Uny, 19(2), 123-130. 
Octaviani, K. D., Indrawatiningsih, N., \& Afifah, A. (2021). Kemampuan Visualisasi Spasial Siswa Dalam Memecahkan Masalah Geometri Bangun Ruang Sisi Datar Kemampuan Visualisasi Spasial Siswa Dalam Memecahkan Masalah Geometri Bangun Ruang Sisi Datar. International Journal of Progressive Mathematics Education, 1(1), 27-40. https://doi.org/10.22236/ijopme.v1 i1.6583

Passolunghi, M. C., Caviola, S., De Agostini, R., Perin, C., \& Mammarella, I. C. (2016). Mathematics anxiety, working memory, and mathematics performance in secondary-school children. Frontiers in Psychology, 7(FEB), 1-8. https://doi.org/10.3389/fpsyg.2016. 00042

Phonapichat, P., Wongwanich, S., \& Sujiva, S. (2014). An Analysis of Elementary School Students' Difficulties in Mathematical Problem Solving. Procedia Social and Behavioral Sciences, 116(2012), 3169-3174. https://doi.org/10.1016/j.sbspro.20 14.01 .728

Radford, L. (2008). Connecting theories in mathematics education: challenges and possibilities. ZDM Mathematics Education, 40(2), 317-327.

https://doi.org/10.1007/s11858008-0090-3

Ruswati, D., Utami, W. T., \& Senjayawati, E. (2018). Analisis Kesalahan Siswa SMP dalam menyelesaikan soal kemampuan pemecahan masalah matematis ditinjau dari tiga aspek. Maju, 5(1), 91-107.
Saida, A., Ikram, M., \& Salwah. (2021). Analysis of Students' Creative Thinking in Solving Cuboid Problems. International Journal of Progressive Mathematics Education, 1(2), 104-116. https://doi.org/10.22236/ijopme.v1 i2.7307

Samo, D. D. (2017). Kemampuan pemecahan masalah matematika mahasiswa tahun pertama dalam memecahkan masalah geometri konteks budaya. Jurnal Riset Pendidikan Matematika, 4(2), 141. https://doi.org/10.21831/jrpm.v4i2. 13470

Sari, L. N. I. (2017). Peningkatan Kemampuan Pemecahan Masalah Matematis Siswa Melalui Pendekatan Pendidikan Matematika Realistik. In Logaritma: Jurnal Ilmu-ilmu Pendidikan dan Sains (Vol. 5, Issue 01, p. 24). https://doi.org/10.24952/logaritma. v5i01.1258

Schukajlow, S., Krug, A., \& Rakoczy, K. (2015). Effects of prompting multiple solutions for modelling problems on students' performance. Educational Studies in Mathematics, 89(3), 393-417. https://doi.org/10.1007/s10649015-9608-0

Sumartini, T. S. (2016). Peningkatan Kemampuan Pemecahan Masalah Matematis Siswa melalui Pembelajaran Berbasis Masalah. Jurnal Pendidikan Matematika STKIP Garut, 5.

Umam, K. (2018). Peningkatan Kemampuan Berpikir Matematis Siswa melalui pembelajaran Reciprocal Teaching. Jurnal Pendidikan Matematika Indonesia, 3(2), 57-61. 
DOI: https://doi.org/10.24127/ajpm.v10i4.4226

Wahyudin. (2008). Pembelajaran dan Model-Model Pembelajaran. UPI.

Warli. (2014). Tantangan Pembelajaran Matematika Dalam Implementasi Kurikulum 2013. Prosiding Seminar Nasional Matematika Dan Pendidikan Matematika, 2000.

Webb, N. M., Franke, M. L., Ing, M., Wong, J., Fernandez, C. H., Shin, N., \& Turrou, A. C. (2013). Engaging with others' mathematical ideas: Interrelationships among student participation, teachers' instructional practices, and learning. International Journal of Educational Research, 63, 79-93. https://doi.org/10.1016/j.ijer.2013. 02.001 